\title{
A randomised cross-over trial to evaluate the impact of tea on measures of hydration
}

\author{
C. H. S. Ruxton ${ }^{1}$ and V. A. Hart ${ }^{2}$ \\ ${ }^{1}$ Nutrition Communications, Front Lebanon, Cupar KY15 4EA, UK and ${ }^{2}$ RSSL, Reading Science Centre, Pepper Lane, \\ Reading RG6 $6 L A, U K$
}

It is often claimed that caffeinated drinks, such as tea, have an adverse effect on hydration. While studies on caffeine pills have produced inconsistent results ${ }^{(1)}$, those on caffeinated drinks, at caffeine intakes of $114-420 \mathrm{mg}$, have found no significant impact on hydration ${ }^{(2,3)}$. However, there have been no randomised controlled trials on tea, as consumed. The present trial aimed to assess the impact of $4 \times 240 \mathrm{ml}$ mugs of black, i.e. regular, tea on blood and urine measures of hydration.

Following informed consent, 21 healthy men, who had abstained from caffeine and intense exercise for $10 \mathrm{~h}$, took part in a randomised, cross-over trial. Black tea with semi-skimmed milk was made, using a standardised protocol, and was drunk at fixed, regular intervals over a 10-h period. Water, at an equivalent volume and temperature, was used as a control. Bloods were taken at baseline and on 5 other occasions over $12 \mathrm{~h}$. Changes in individual blood parameters between baseline and $12 \mathrm{~h}$ (time 12 minus time 0 ), for the 16 subjects whose results were available, are shown below:

\begin{tabular}{|c|c|c|c|c|c|c|c|}
\hline $\begin{array}{l}\text { Change from } \\
\text { baseline }\end{array}$ & $\mathrm{K}(\mathrm{mmol} / \mathrm{l})$ & $\mathrm{Na}(\mathrm{mmol} / \mathrm{l})$ & $\mathrm{HCO}_{3}(\mathrm{mmol} / \mathrm{l})$ & Total protein $(\mathrm{g} / \mathrm{l})$ & Urea $(\mathrm{mmol} / \mathrm{l})$ & Creatine $(\mathrm{mmol} / \mathrm{l})$ & Osmolality $(\mathrm{mosmo} / \mathrm{kg})$ \\
\hline Water & -0.10 & +0.60 & +0.20 & +1.79 & +0.69 & +1.07 & +2.06 \\
\hline Tea & -0.08 & +0.55 & +0.18 & +1.70 & +0.96 & +1.24 & +3.65 \\
\hline$P<$ & NS & NS & NS & NS & NS & NS & NS \\
\hline
\end{tabular}

Urine was collected over $24 \mathrm{~h}$ and analysed. Comparisons in $24 \mathrm{~h}$ urine parameters between the water control and tea condition for the same 16 subjects are presented below:

\begin{tabular}{lcccccccc}
\hline & Volume $(\mathrm{l})$ & Creatinine $(\mu \mathrm{mol} / 24 \mathrm{hr})$ & $\mathrm{Na}(\mu \mathrm{mol} / 24 \mathrm{~h})$ & $\mathrm{K}(\mu \mathrm{mol} / 24 \mathrm{~h})$ & Osmolality $(\mathrm{mosmo} / \mathrm{kg})$ & Creatinine $(\mathrm{mmol} / \mathrm{l})$ & $\mathrm{Na}(\mathrm{mmol} / \mathrm{l})$ & $\mathrm{K}(\mathrm{mmol} / \mathrm{l})$ \\
\hline Water & 1.357 & 15884 & 108.3 & 72.0 & 634 & 12245 & 87.69 & 53.74 \\
Tea & 1.062 & 14180 & 107.1 & 60.0 & 744 & 14066 & 104.5 & 58.1 \\
$P<$ & $\mathrm{NS}$ & $\mathrm{NS}$ & $\mathrm{NS}$ & $\mathrm{NS}$ & $\mathrm{NS}$ & $\mathrm{NS}$ & $\mathrm{NS}$ & NS \\
\hline
\end{tabular}

No significant differences were found between tea and water for any of the blood or urine parameters. This suggests that tea is equally hydrating to water at an intake of 4 mugs per d, equivalent to a daily caffeine intake of about $200 \mathrm{mg}$.

The research was funded by the Tea Advisory Panel.

1. Ruxton CHS (2008) The impact of caffeine on mood, cognitive function, performance and hydration: a review of benefits and risks. Nutr Bull 33, $15-25$.

2. Grandjean AC, Reimers KJ, Bannick KE et al. (2000) The effect of caffeinated, non-caffeinated, caloric and non-caloric beverages on hydration. $J$ Am Coll Nutr 19, 591-600

3. Fiala KA, Casa DJ \& Roti MW (2004) Rehydration with a caffeinated beverage during the nonexercise periods of 3 consecutive days of 2-a-day practices. Int J Sport Nutr Exerc Metab 14, 419-429. 